\title{
Changes in Gene Expression in Needles and Stems of Pinus radiata Rootstock Plants of Different Ontogenic Age
}

\author{
Carolina Alvarez1,2*, Luis Valledor ${ }^{3}$, Patricia Sáez1, Rodrigo Hasbún1, \\ Manuel Sánchez-Olate1, María Jesús Cañal ${ }^{4}$, Darcy Ríos ${ }^{1}$ \\ ${ }^{1}$ Laboratorio de Cultivo de Tejidos Vegetales, Facultad de Ciencias Forestales y Centro de Biotecnología, \\ Universidad de Concepción, Concepción, Chile \\ ${ }^{2}$ Centro Tecnológico de la Planta Forestal (CTPF), Instituto Forestal (INFOR), Sede Bío-Bío, Chile \\ ${ }^{3}$ Laboratories of Adaption Biotechnologies, Global Change Research Centre, Academy of Sciences of the \\ Czech Republic, Brno, Czech Republic \\ ${ }^{4}$ Plant Physiology, Epiphysage Research Group, Biology of Organisms and Systems Department, Faculty of \\ Biology, University of Oviedo, Oviedo, Spain \\ Email: "caalvarez@udec.cl
}

Received 6 February 2016; accepted 10 June 2016; published 13 June 2016

Copyright (C) 2016 by authors and Scientific Research Publishing Inc.

This work is licensed under the Creative Commons Attribution International License (CC BY).

http://creativecommons.org/licenses/by/4.0/

(c) (i) Open Access

\begin{abstract}
A major problem in forest clonal productivity is the loss of morphogenetic capability with the increasing age of plants. However, despite of the importance of loss of morphogenetic competence, very little research has been done about the underlying mechanisms involved in this process. For this reason, a gene expression analysis using dot blot technique was performed in needles and stems of 1- and 3-year old Pinus radiata rootstock plants with a proved decrease in morphogenetic competence. Needles of one year old rootstock plants showed a higher number of up-regulated in genes mainly corresponding to photosynthesis and protein synthesis, degradation and modification, reflecting a higher number of active pathways in younger hedges, contrary to the older ones. Gene expression profiles found in stems are in agreement with those found in needles, indicating more active pathways in younger rootstock plants than in older ones. Several transcripts regulating transcription and translation were up-regulated in young competent tissues. Three-year-old stems presented an increase in the expression of an ethylene response factor, involved in plant organ senescence, indicating that pathways involved in senescence and ageing might inhibit the adventitious root formation, as in the older cuttings.
\end{abstract}

${ }^{*}$ Corresponding author.

How to cite this paper: Alvarez, C., Valledor, L., Sáez, P., Hasbún, R., Sánchez-Olate, M., Cañal, M.J. and Ríos, D. (2016) Changes in Gene Expression in Needles and Stems of Pinus radiata Rootstock Plants of Different Ontogenic Age. American Journal of Plant Sciences, 7, 1205-1216. http://dx.doi.org/10.4236/ajps.2016.78116 
Keywords

Plant Ageing, Gene Expression, Morphogenetic Competence, Pinus radiate

\section{Introduction}

In terms of annual wood production, Pinus radiata D. Don is one of the most important forestry species in the world, with almost $25 \%$ of the world's production. In Chile, due to its importance, rooting of woody cuttings is being used to capture the genetic gain and produce large amounts of plant material from "superior clones", which are selected from control-pollinated orchards [1]. Unfortunately, this practice is severely affected by the age of rootstock plants; being widely known that tree maturation is one of the most important obstacles in the development of selected clones [2] [3]. Thus, in woody species, the loss of morphogenetic competence is a consequence of maturation and ageing, this implies a barrier for plant multiplication or regeneration. Therefore, upgrading forestry programs face the problem of selecting interesting traits during the mature age, while vegetative propagation is only possible during juvenile phases of development [2]. In relation to the latter, four phases of maturation have been recognized 1) embryonic phase, 2) post-embryonic juvenile vegetative phase 3) adult vegetative phase and 4) the adult reproductive phase [4]. In gymnosperms, maturation is associated with decrease growth rates during phases 2 - 4, increased plagiotropism, and changes in reproductive competence, branching characteristics and foliar morphology, with the most pronounced changes occurring between ages 1 and 4 years. This indicates that, loss of morphogenetic competence or ageing is not strictly associated to the onset of flowering, and in the specific case of Pinaceae these changes are abrupt, irreversible and can occur in the early stages of the plant life cycle [5] [6].

The most consistent evidence of the maturational process is the decrease in the ability of cuttings to produce adventitious roots, decreasing the rooting rates with the increase of rootstock age [7] [8]. Research in Pinus tae$d a$ [6] [9] in hedges from 1 to 2 year old presented a marked decrease in rooting compared with hypocotyls cuttings of 20 to 25 days old; and only after 50 days after germination in response to auxin. The same results were found in Pinus banksiana [10]. These results indicate that adventitious rooting decline and ageing are highly correlated processes. Although it has been suggested that this decline could be due to the loss in competence at the cellular level [11], the intrinsic mechanism behind the loss of morphogenetic competence due to ageing has not been researched in pine species. Most studies have been focused mainly in morphological traits [1] [12] and hormone action [13]-[15], but due to maturation implies a loss in morphogenetic capability, it is highly likely that this phenomenon causes changes in gene and protein expression. Some genes have been proposed as regulators of the rooting process in Pinus contorta hypocotyls: two S-adenosylmethionine genes (PcSAMS1 and PCSAMS2) [16], a PINHEAD/ZWILLE gene [17], SCARECROW-LIKE gene [18] and a SHORT-ROOT gene [19]. However, little has been reported about the molecular mechanisms involved in plant ageing and in woody species.

Only one research was reported, concerning changes in gene expression in relation to loss of morphogenetic capability [20]. Combined proteomic and trascriptomic techniques described changes in mRNA and protein species that characterize the needle maturation developmental process in Pinus radiata. Since maturation of the complete tree is a very complex process, the first step was to study individual organs. Because needles are the main source employed for tree cloning and in vitro micropropagation, they are ideally suited to study maturation. According to the above, 176 genes obtained from a SSH library were differentially expressed between $P$. radiata immature (competent tissues) and mature needles (incompetent tissues), and may explain differences in morphogenetic competence. Mature needles were characterized by an overexpression of energy-related and photosynthetic pathways, while immature needles overexpressed genes related to stress and defense mechanisms.. Based on these results, we evaluated changes in gene expression in needles and stems of $P$. radiata woody cuttings, of ages typically used as rootstock plants in forest nurseries. Additionally, we also evaluated rooting rates and anatomy. We hypothesized that genes differentially expressed through needle maturation can be altered due to ontogenic ageing in needles and stems of 1 and 3-year-old $P$. radiata rootstock plants. To prove this hypothesis, we select 176 genes that cover different areas of metabolism, which, were tested in needles and stems of 1 and 3-year-old $P$. radiata rootstock plants with decrease in morphogenetic capability. This research represents the first approach describing the main metabolic pathways involved in P. radiata ontogenic ageing. 


\section{Materials and Methods}

\subsection{Plant Material}

Plant material was obtained from Proplantas Nursery S.A located in Bio-Bio region in central Chile, with coordinates, $36^{\circ} 37^{\prime} 25.87^{\prime \prime S}$ and $72^{\circ} 21^{\prime} 23.80^{\prime \prime} W$. Plant material corresponds to rootstock plants of 1 and 3-year-old from the same full-sib family, and cultivated under the same conditions of fertilization and watering. In brief, the collection of plant material was performed in August of 2012, $250 \mathrm{mg}$ of fresh material from needles and the base of the stem cuttings were collected with liquid nitrogen and stored at $-80^{\circ} \mathrm{C}$ until needed for RNA extraction.

For the stem cutting rooting procedure, the cuttings were rooted on the nursery of the Forestry Science Faculty of the Universidad de Concepción according to Proplantas S.A. nursery protocol for container rooting. In brief: cuttings were washed with a $0.5 \mathrm{~g} / \mathrm{l}$ benomilo solution to avoid fungal contamination. Then, cuttings were placed in containers type Arauco (88 cavities, $130 \mathrm{~cm}^{3}$ ) with pine bark compost as substrate. Cuttings were irrigated three times a day to maintain foliage and substrate wet at field capacity. Rooting percentage was evaluated until younger cuttings reached $100 \%$ of rooting.

\subsection{Needle and Stem Anatomy}

Fully developed needles and the basal portion of 1 and 3-year-old $P$. radiata cuttings were analyzed microscopically using OLYMPUS CX31. Plant material was previously fixed in formaldehyde, acetic acid and ethanol (FAA), for $72 \mathrm{~h}$ and preserved in $70 \%$ ethanol (v/v). Transverse sections of 10 um were obtained using a microtome. The sections were stained with safranine-fast green and mounted in water-glycerol for microscopic observation [21]. Photographs were analyzed using Image J software. In needles, the width of epidermis, hypodermis and epidermis, percentage of vascular cylinder and resin canal diameter were measured. In stems, the diameter of whole stem, xylem and phloem and periderms width were measured.

\subsection{RNA Extraction and cDNA Synthesis}

RNA extraction was performed following a CTAB protocol [22]. Total RNA was purified with the RNeasy Clean Up kit from Qiagen [23]. Purified RNA was diluted with RNase-free water and stored at $-80^{\circ} \mathrm{C}$ until use. One $\mu \mathrm{g}$ of total RNA was reverse transcribed with Superscript III first strand synthesis kit (Invitrogen) to obtain target cDNA, which was marked with digoxigenin (Roche) and Terminal Transferase kit (Roche).

\subsection{Probes Synthesis for Dot Blot}

Differential gene expression was assessed using dot blot technique with samples of plant material described above. Probes correspond to candidate genes associated to $P$. radiata needle maturation and loss of morphogenetic competence, which were previously obtained using a suppressive subtractive (SSH) library [20]. The probes correspond to a 176 cDNA (supplementary material), belonging to the following functional categories obtained according to KEGG: photosynthesis, mitochondria (electron transfer), carbohydrates and carbon metabolism, cell wall, lipid metabolism, nitrogen and aminoacid metabolism, transcription and DNA replication, protein translation folding modification and degradation, secondary metabolism cytoskeleton, stress and defense related proteins, signaling, transport and cell cycle and morphogenesis. cDNA was PCR amplified directly from E. coli clones employing SP6 (primer sequence: ATTTAGGTGACACTATAG) and T7 primers (primer sequence: TAATACGACTCACTATAGGG) (PCR program: $94^{\circ} \mathrm{C}$ for $20 \mathrm{~s}, 50^{\circ} \mathrm{C}$ for $30 \mathrm{~s}, 72^{\circ} \mathrm{C}$ for $70 \mathrm{~s}$ ) and a final extension of $7 \mathrm{~min}$ at $72^{\circ} \mathrm{C}$. Resultant PCR products were mixed with $1.5 \mathrm{M} \mathrm{NaOH}, 300 \mathrm{mM}$ EDTA pH 8.2 to reach a final concentration of $400 \mathrm{mM} \mathrm{NaOH}, 80 \mathrm{mM}$ EDTA. Three $\mu \mathrm{L}$ of each cDNA clone were spotted into a positively charged nylon Hybond $\mathrm{N}+$ membrane (GE healthcare).

\subsection{Dot Blot Procedure}

Membranes were pre-hybridized with Church buffer (0.5 M phosphate buffer, $10 \mathrm{mM}$ EDTA, 7\% SDS and 1\% BSA) for an hour. Target cDNA was added to a fresh buffer to reach a final concentration of $50 \mathrm{ng} / \mathrm{ml}$ and hybridized over night at $55^{\circ} \mathrm{C}$. After three consecutive washes in $2 \times$ SSC- $0.1 \%$ SDS, $2 \times$ SSC- $0.1 \%$ SDS and $1 \mathrm{x}$ SSC- $0.1 \%$ SDS, the membranes were treated with CSPD ready to use (Roche) chemilumiscence subtract ac- 
cording to the manufacturer instructions. Blots were imaged exposing them to a CL-Xposure film (Thermo Scientific) for 30 minutes. Images were analyzed using a dot blot analyzer for Image J. Global normalization was adopted for normalizing the difference of signal intensity of each nylon filter: the intensity of all the spots on the filter was averaged and the relative signal intensity was calculated as the ratio of each signal to the average intensity of each filter.

\subsection{Quantitative RT-PCR (qRT-PCR)}

To validate results found with dot blot, five genes that might be related to ageing and that were differentially expressed were selected for qRT-PCR. The qRT-PCR was performed as follows: extraction of RNA, purification, quantification and cDNA synthesis (as previously described). The primer pairs were design with Primer3Plus software. qRT-PCR was performed with $300 \mathrm{nM}$ of each forward and reverse primer and $12.5 \mu \mathrm{L}$ of 2X Power SYBR Green PCR master mix (Applied Biosystems) to reach a final concentration of $1 \times$, according to the manufacturer instructions. The PCR reaction was performed in a Step-One Plus real-time PCR system (Applied Biosystems). Polymerase chain reaction efficiency was estimated by template dilutions and the equation $E=10^{(-1 / \text { slope })}$ [24]. Five biological replicates and three technical replicates were used. Specific primers are listed in Table 1; the ubiquitin gene was used as internal control. Expression ration were obtained using the method of $2^{-\Delta \Delta \mathrm{Ct}}$.

\subsection{Statistical Design and Analysis}

After global normalization (as described above) a Student's $t$ test was carried out to compare between 1-and 3year-old rootstock plants, results were considered to be statistically significant a $P<0.05$. Gene expression of needles and stems were evaluated by separate. The TTEST procedure was used for Student's $t$ test with SAS statistical software. The same approach was used to compare for histological measurements and morphological competence assessment. Clustering analysis was done using the cluster 3.0 software and Java Tree View software for cluster visualization; the gene tree was created using the average linkage clustering method (Pearson correlation).

\section{Results}

\subsection{Effect of Rootstock Age on Morphogenetic Capability, Needle and Stem Anatomy}

The rooting capability of cuttings from 1 and 3 year old rootstock plants was evaluated to assess the morphogenetic capability of rootstock plants. After two months from the beginning of the rooting procedure almost $100 \%$ of 1-year-old cuttings had root primordium, while in 3-year-old cuttings only $20 \%$ showed this response (Table 2). Cuttings from 1-year-old rootstock plants formed a thickening at the base of the cutting within 15 days from the initiation of the rooting process, at this time point it is possible distinguish the initial formation of root primordium. Cuttings from 3-year-old rootstock plants presented the same response at 30 days from the initiation of the rooting process.

Table 1. List of primers used in quantitative real time PCR (qRT-PCR), forward and reverse primer sequence are written in direction 5' to 3'. Gene name, NCBI accession number and primers melting temperatures are described.

\begin{tabular}{cccccc}
\hline Gene name & NCBI accession number & Forward primer $\left(\mathbf{5}^{\prime}->\mathbf{3}^{\prime}\right)$ & Reverse primer (5' -> 3') & Tm $\left(\mathbf{~}^{\prime} \mathbf{C}\right)$ \\
\hline CAB & GO096311 & AGAGCTGTTGACTAAGTTGGG & AGATTGGATCGGTGTTGACTG & 54 \\
DI19 & GO096128 & ATAGATGCCCATGCTGTGTAG & CTTCCCTCTGTTCCCACTTG & 54 \\
CAOMT & GO096097 & CTTCGTCTCTGTCAGGTGTG & TACAGTCCTCATCGTCCAG & 56 \\
TRPS & GO096137 & AGATGGAGGACCACAGATTT & CCGATGTGTTTAGCAAGAAG & 56 \\
SPD & GO096159 & GCAATAAGTTGAGGCGATCT & CAAACCATCCAGGAATAACA & 55 \\
\hline
\end{tabular}

Abbreviations: CAB—Chlorophyll a/b binding protein; DI19—Dehydration induced protein 19; CAOMT—Caffeic acid O-methyltransferase; TRPS—Tryptophan synthase $\beta$ subunit; SPD—Spermidine synthase. 
Table 2. Anatomical characteristics of needles and stems of 1 and 3-year-old Pinus radiata rootstock plants, and cuttings rooting capability after 2 months. Values \pm standard deviation, different letters correspond to significant differences according to Student's $t$ test for $P<0.05$.

\begin{tabular}{ccc}
\hline & \multicolumn{2}{c}{ Rootstock plant age } \\
\hline & 1-year-old & 3-year-old \\
\hline Needles anatomical characteristics & \\
\hline Mesophyll width $(\mu \mathrm{m})$ & $181.3 \pm 20.7$ (a) & $76.6 \pm 7.6$ (b) \\
Epidermis width $(\mu \mathrm{m})$ & $18.6 \pm 1.9$ (a) & $16.2 \pm 2.3$ (b) \\
Hypodermis width $(\mu \mathrm{m})$ & $0.03 \pm 0.04$ (b) & $15.7 \pm 1.9$ (a) \\
\% Vascular cylinder & $14.5 \pm 0.5(\mathrm{~b})$ & $41.6 \pm 0.4$ (a) \\
Resin canal $\left(\mu \mathrm{m}^{2}\right)$ & $2013.0 \pm 235,4$ (b) & $2741.7 \pm 763.6$ (a) \\
\hline Stems anatomical characteristics & $3717.5 \pm 170.7$ (a) \\
\hline Total diameter $(\mu \mathrm{m})$ & $2355.6 \pm 209.2$ (b) & $811.4 \pm 13.4$ (a) \\
Xylem diameter $(\mu \mathrm{m})$ & $461.7 \pm 74.2$ (b) & $149.1 \pm 12.0$ (a) \\
\hline Phloem diameter $(\mu \mathrm{m})$ & $119.6 \pm 10.2$ (a) & $117.5 \pm 1.3$ (a) \\
\hline Periderm width $(\mu \mathrm{m})$ & $81.5 \pm 8.5$ (b) & \\
\hline
\end{tabular}

One-year-old needles (Figure 1(a)) presented less developed tissues, showing only one vascular bundle while 3-year-old needles (Figure 1(b)) presented two vascular bundles. Moreover, needles from 3-year-old rootstock plants formed a hypodermis, unlike 1-year-old that lacked this formation. On the other hand, younger rootstock plants showed higher values of mesophyll and epidermis width (Table 2) and lower values of hypodermis width and percentage of vascular cylinder (Table 2). In the same way stem tissues were significantly more developed in older rootstock plants; total diameter, xylem and cortex widths were greater in 3-year-old stems compared to younger 1-year old stems (Figure 1(c) and Figure 1(d), Table 2).

\subsection{Effect of Rootstock Plant Age on Pinus Radiata Needle Gene Expression}

Changes in gene accumulation patterns with rootstock plants ageing was evaluated, by comparing 1 and 3-yearold of $P$. radiata needles. From the 176 tested cDNAs, 36 were differentially expressed between both ages, from which 32 increase their accumulation in needles from 1-year-old rootstock, and 4 increased their accumulation in 3-year-old (Figure 2). Cluster analysis generated two clearly differentiated clusters; differentiating genes with an increase in gene expression in three year old cuttings in the minor cluster and genes up-regulated in younger cuttings in the mayor cluster.

The four accumulated genes in older cutting needles belong to several functional categories such as: stress and defense, carbohydrate metabolism, signaling and transport. Genes related to photosynthesis were mainly up-regulated in 1-year-old cuttings such as: type II chlorophyll A-B binding protein precursor, Rubisco small subunit, photosystem II D2 (PSBD), photosystem II CP43 (PSBC) proteins, and photosystem II core complex $P S B Y$ protein. Also, this tissue presented an increase in expression of genes related to transcription and DNA replication such as the transcription elongation factor 1-alpha.

\subsection{Effects of Rootstock Plant Age on Pinus Radiata Stem Gene Expression Patterns}

Changes in gene expression patterns were assessed in the stem of $P$. radiata cuttings from 1 and 3-year-old rootstock plants. From the 176 cDNAs tested only 30 were differentially expressed between both types of rootstock plants; similar to the results from pine needles, the majority of genes presented increased gene expression in younger cuttings. Out of the 30 differentially expressed genes, 22 presented higher accumulation in 1-year-old 


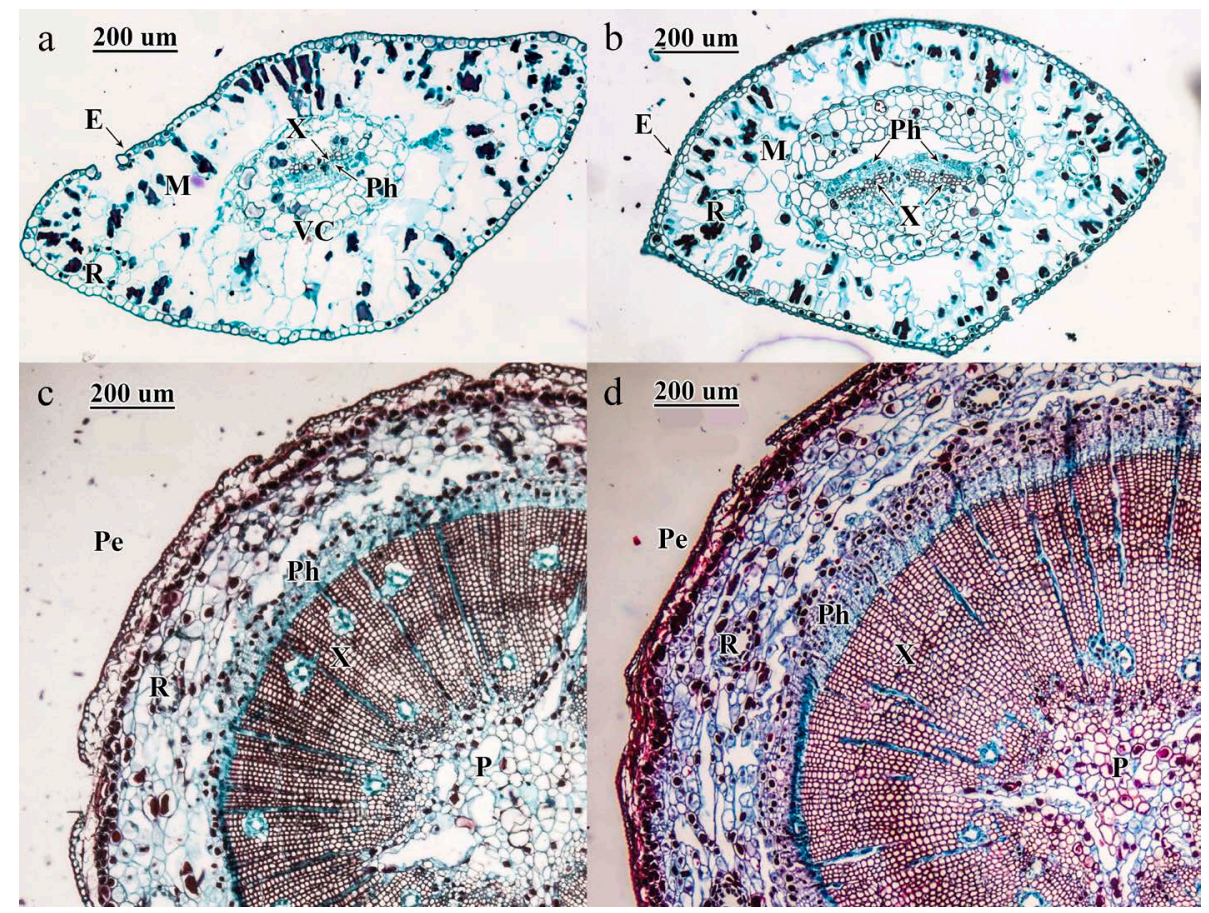

Figure 1. Cross section of needles and cuttings of Pinus radiata rootstock plants. Needles from 1-year-old; (a) and 3-year-old; (b) rootstock plants, and cross section of cuttings of stems from 1-year-old; (c) and 3 year-old; (d) rootstock plants. M: mesophyll, E: epidermis, R: resin canal, X: xylem, Ph: phloem and VC: vascular cylinder, P: pith, Pe: periderm. Bar represent $200 \mu \mathrm{m}$. Figures were obtained with a 10× magnification.

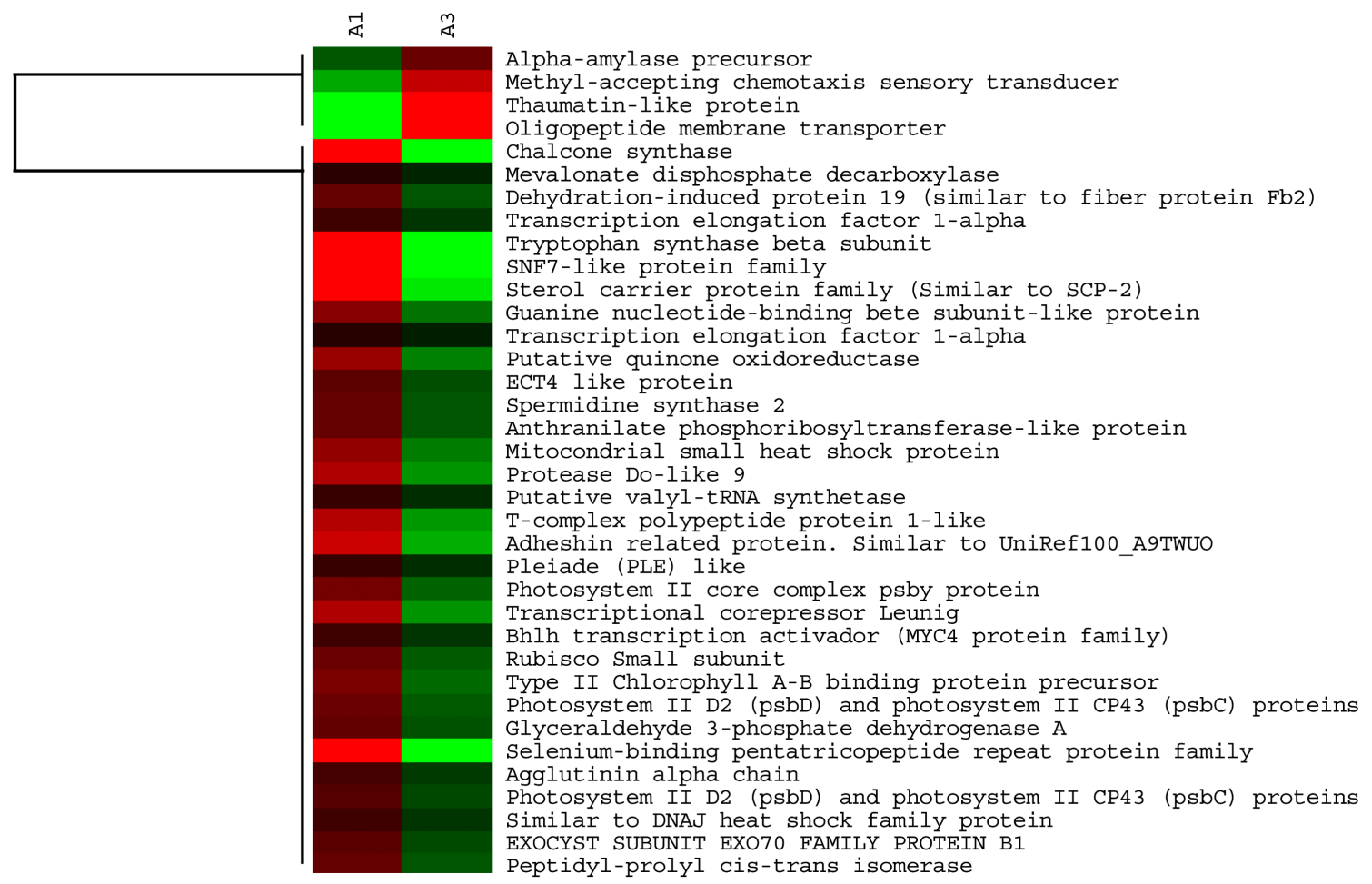

Figure 2. Hierarchical clustering of 36 genes differentially expressed between needles of 1 and 3-year-old Pinus radiata rootstock plants. The gene tree was created using the average linkage clustering method (Pearson correlation). Red and green represents up and down gene expressions, respectively. A1: 1-year-old rootstock plants, A3: 3-year-old rootstock plants. 
$P$. radiata stems, while only 8 increase their accumulation in the 3-year-old (Figure 3). Also, the cluster analysis generated two clearly differentiated clusters according to changes in accumulation between both rootstock ages. The first cluster includes genes that have higher mRNA levels in younger stems, while the second cluster presents genes with higher expression in older stems.

The eight genes with higher accumulation in 3-year-old plants belong to several functional categories such as: carbon metabolism, secondary metabolism, stress and defense. Among these genes there are two genes belonging to the category of transport like oligopeptide membrane transporter and exocyst subunit EXO70 family protein B1. On the other hand, genes with higher gene expression in 1-year-old stems have functions related to protein folding, modification and degradation such as: translation elongation factor 1-alpha, putative valyl-tRNA synthase and eukaryotic initiation factor 4-like protein. Transcripts involved in transcription and DNA replication are also represented among genes up-regulated in 1-year-old stems.

Gene expression results are in agreement with genes tested through real time qRT-PCR (Table 3), the type II chlorophyll a/b binding protein, spermidine synthase and tryptophan synthase $\beta$ subunit presented the same tendency in dot-blot and qRT-PCR measurements. Caffeic acid-O-methyltransferase did not show a significant change in neither dot blot nor qRT-PCR for needle results. Also, the DI19 gene presented a significant increase in needles and stems from 1-year-old rootstock plants, in qRT-PCR. On the other hand, the DI19 gene did not

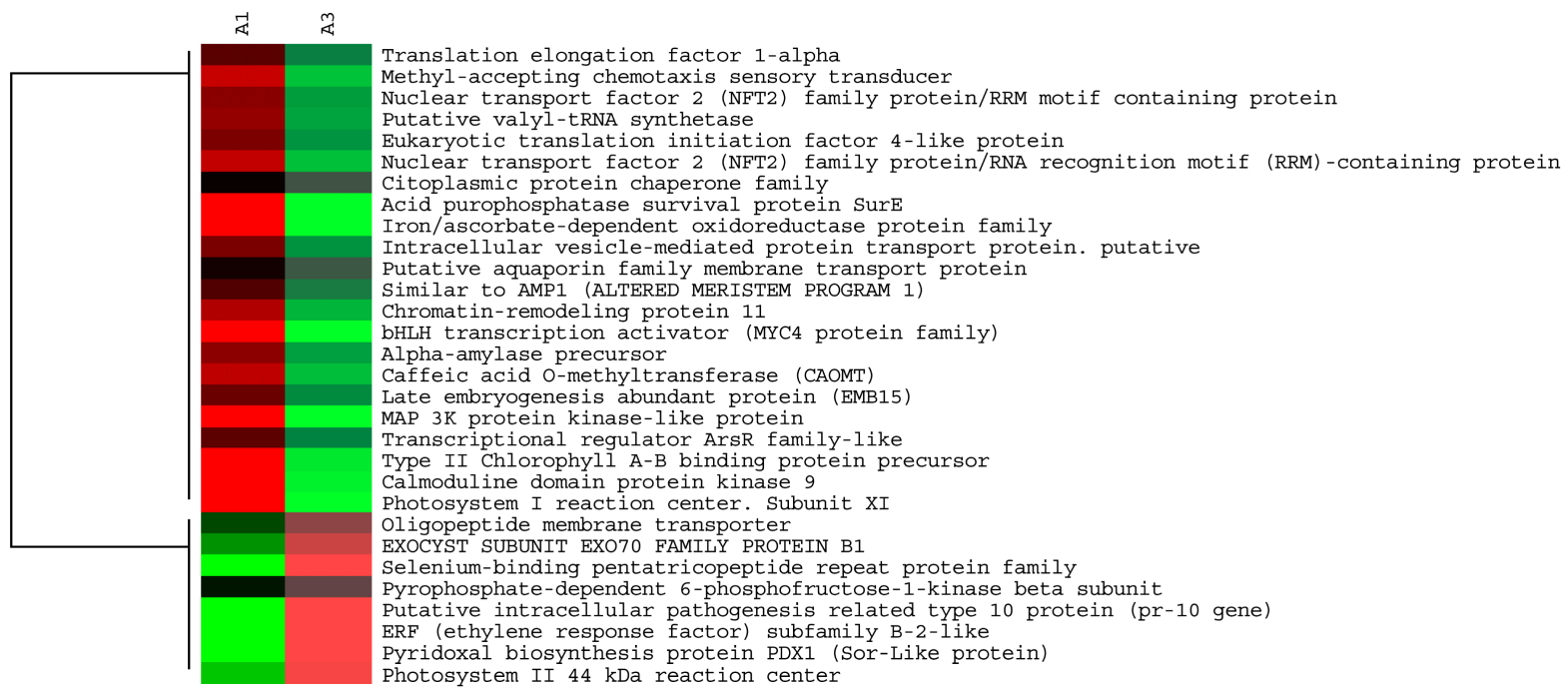

Figure 3. Hierarchical clustering of 30 genes differentially expressed stems of 1 and 3-year-old rootstock of Pinus radiata plants. A gene tree was created using the average linkage clustering method (Pearson correlation). Red and green represents up and down gene expressions, respectively. A1: 1-year-old rootstock plants; A3: 3-year-old rootstock plants.

Table 3. Quality control of dot-blot experiments. Fold \pm SE change differences of five different cDNAs were confirmed by real time qRT-PCR. Gene name in indicated. Negative and positive ratios indicate decreased and increased mRNA accumulation respectively, results are shown relative to 1 year-old rootstock plants. Fold changes were considered significant over 2-fold.

\begin{tabular}{ccc}
\hline & & Fold change \pm SE \\
\cline { 2 - 3 } Gene name & Needles & Stems \\
\hline CAB & $+2.78 \pm 0.260$ & $+2.65 \pm 0.634$ \\
SPD & $+6.56 \pm 0.392$ & $+1.92 \pm 0.127$ \\
TRPS & $+2.73 \pm 0.284$ & $+1.85 \pm 0.086$ \\
DI19 & $+3.11 \pm 0.360$ & $+4.43 \pm 0.222$ \\
CAOMT & $+1.61 \pm 0.286$ & $+3.16 \pm 0.149$
\end{tabular}

Abbreviations: CAB—Chlorophyll a/b binding protein; DI19—Dehydration induced protein 19; CAOMT—Caffeic acid O-methyltransferase; TRPS-Tryptophan synthase $\beta$ subunit; SPD-Spermidine synthase. 
showed significant differences on dot blot results. However, in dot blot this gene presented a tendency to an increase accumulation in younger needles and stems but without statistical significance. Thus, it is well known that hybridization techniques, as in the case of dot blot, tend to underestimate qRT-PCR values.

\section{Discussion}

Changes in gene expression between $P$. radiata rootstock plants of 1 and 3-years-old with differences in their morphogenetic capability were evaluated. Our results showed that rootstock plant age induces changes on rooting capability and in needles and stems anatomy. Quicker and earlier response in younger 1-year-old cuttings and higher rooting rates, are in agreement with several researches that indicate that capability for rooting is lost between 3 and 5 year old in gymnosperms [6] [10] [11] [25] [26]. Anatomical changes observed in both types of needles are in agreement with reports in Douglas-fir and P. halepensis [27] [28], indicating anatomical differences between young and old needles. Needles from younger trees presented a smaller vascular cylinder and increased mesophyll area. These anatomical characteristics are often related with decrease in photosynthesis observed in increased-age individuals [29]. In this regard, changes in mRNA levels in genes related to photosynthesis were also found between both types of needles. Genes such as: type II chlorophyll A-B binding protein (CAB) precursor, photosystem II D2 (PSBD) and photosystem II CP43 (PSBC) proteins, photosystem II core complex PSBY protein, RuBisCO small subunit (RBCS) and glyceraldehyde 3-phosphate dehydrogenase A, decreased their accumulation in 3-year-old needles. This is in agreement with reports indicating that photosynthesis parameters are reduced with the increasing age of shrubs and trees [29]-[31]. At mRNA level, the CAB gene mRNAs are accumulated in juvenile needles of larch and young leaves of Arabidopsis [32] [33]. Additionally, $R B C S$ gene is highly regulated at transcriptional level during developmental processes and differentiation in tomato [34] [35]. On the contrary, genes related to photosynthesis as the ones mentioned above, presented an opposite tendency they were up-regulated in mature needles and down-regulated in immature ones [20], indicating that these genes reveal differential gene expression for needle maturation process and needle ontogenic ageing.

According to the analysis of differentially expressed genes, we found that from 176 genes tested only 36 were differentially expressed between 1 and 3-year-old rootstock plants. Most of the age-regulated genes (32) were accumulated in the younger rootstock needles. Also, changes in gene expression between stems from juvenile 1-year-old and 3-year-old rootstock plants were determined. Similar to the results in needles, 1-year old stems showed 22 highly accumulated genes against the 8 accumulated transcripts in older stems. These results are in agreement with a previous study [20], where most of genes and protein evaluated were overexpressed/accumulated in immature needles, (Figure 2 and Figure 3), and two main branches can be distinguished separating 1 year-old rootstock plants from the 3-year-old ones.

Among differences determined, our results showed an increase in spermidine synthase (SPD) transcript abundance in needles of 1-year-old rootstock plants. Transcripts of this gene are more accumulated in younger than older apple leaves, similar to the results obtained in alfalfa for enzymatic activity levels [36]-[38]. Polyamine levels, such as spermidine, spermine and putrescine, have been reported as a physiological marker of ageing, maturation, and loss of morphogenetic capability [39] [40]. Tryptophan synthase b subunit (TRPS) gene, responsible for the synthesis of the amino acid tryptophan whose biosynthetic pathway produces the hormone indole-3-acetic acid (IAA) [41], had also greater accumulation in needles from 1-year-old rootstock plants. In this regard, an increase in IAA contents in younger needles and a decrease of this hormone during changes from juvenile to adult vegetative phases occur in $P$. radiata and $P$. pinea [14] [42]. This agrees with the higher levels of the anthranilate-phosphoribosyl transferase transcript determined in 1 year-old-needles, enzyme that is also part of tryptophan biosynthetic pathway [43].

Several genes involved in transcription activation and translation regulation were accumulated in needles and stems from younger 1-year-old rootstock plants. In needles, the transcriptional corepressor leunig, two-transcription elongation factor 1-alpha, a putative valyl-tRNA synthase were modified. Also, a bHLH transcriptional activator (MYC4) presented increased transcript levels in needles and stems from 1-year-old rootstock plants. This transcription factor has been found associated to multiple cellular differentiation pathways in many plant species indicating that the $b H L H$ transcription factor is accumulated in immature needles with high morphogenetic potential [20] [44]. According to our results, transcripts related with translation were accumulated in stems from 1-year-old rootstock plants, a translation elongation factor 1-alpha, putative valyl tRNA synthase and eukaryotic translation initiation factor 4-like proteins are among these. Two nuclear transport factor 2 (NTF2) family 
protein/RNA recognition motifs $(R R M)$ presented higher transcript levels in 1-year old stems. NTF2 is a protein required for efficient import of nuclear protein in to the nucleus [45]. Additionally, $R R M$ are involved in most post-transcriptional gene expression processes (i.e. mRNA and rRNA processing, RNA export and stability) [46], indicating that younger stems would be highly regulated and active at protein synthesis and transport levels.

Ethylene response factor $(E R F)$ presented higher levels of mRNA in stems from 3-year-old rootstock plants. The $E R F$ s are transcription factors that regulate the expression of several downstream target genes by binding to cis-regulatory elements in their promoters [47], and act in the ethylene perception and signal transmission cascade [48]-[50]. ERFs has been induced at transcriptional level by ethylene treatment in hybrid aspen (Populus tremula $x$ Populus tremuloides), indicating that the presence of this hormone can induce an increase in the transcription of ERFs [51], as occurred in 3-year-old stems. Ethylene act in response to a diverse group of stimuli, especially organ senescence [52] [53], this could be related to the increased accumulation of an ERF in older P. radiata stems. However, ethylene and ERFs are also involved in wood formation process and lignin deposition [54] and the application of exogenous ethylene can enhance xylem growth [51] [55]. This is in agreement with the results observed regarding to anatomical changes between juvenile and aged $P$. radiata stems. An increase in the presence of xylem and periderms, indicative of secondary growth, was found in stems of 3-year-old rootstock plants.

Finally, a caffeic acid O-methyltransferase (CAOMT) gene, implicated in monolignols synthesis in gymnosperms [56] [57], was accumulated in 1-year-old stems, indicating that lignin biosynthesis may be more active in juvenile tissues. Also, this gene is as well implicated in plant stress response [57] [58], and these results are in agreement with Valledor et al. (2010) indicating that younger plants increase the expression of gene related to stress responses, which may be related to higher growth rate and fragility against biotic and abiotic stresses.

For non-model species like $P$. radiata, for which most of the high throughput technologies, such as microarray and next generation sequencing, and a reference genome were not available until recently, there is an increase in the usefulness of the dot blot technique used in this research. Dot blot allowed the customized expression analysis of genes of interest during the process of ageing, a poorly described process. We were able to perform the first screening analysis dealing with the main metabolic pathways involved in P. radiata ontogenic ageing.

\section{Conclusion}

These analyses clearly showed a differentiation between juvenile and aged rootstock plants, both in needles and stems. Thus, juvenile rootstock plants were characterized by an increase in the expression of photosynthesis genes, and genes related to activation of transcription and translation. On the contrary, aged 3-year-old rootstock plants were characterized by a low amount of genes accumulated on these tissues, and the overexpression of a senescence related gene. Although quantification of gene expression is the first step to assign gene function, additional experimental work is needed to support the conclusions of this paper. And though we indicate that there are interesting gene patterns that can be associated to plant ageing and loss of morphogenetic competence, experiments are currently being undertaken in our lab exploring this hypothesis.

\section{Acknowledgements}

Authors would like to DIUC 211.142.031-1.0 research projects, MECESUP scholarship, Proplantas S.A nursery and Ph.D. Ingrid Aguayo Fuentealba from Grand Valley State University for her valuable help.

\section{References}

[1] Menzies, M.I., Holden, D.G. and Klomp, B.K. (2001) Recent Trends in Nursery Practice in New Zealand. New Forest, 22, 3-17. http://dx.doi.org/10.1023/A:1012027013173

[2] Valledor, L., Rodríguez, R., Sánchez, P., Fraga, M., Berdasco, M., Hasbún, R., Rodríguez, J.L., Pacheco, J.C., García, I., Uribe, M., Ríos, D., Sánchez-Olate, M., Materán, M.E., Walter, C. and Cañal, M.J. (2007) Propagation of Pinus Genotypes Regardless of Age. In: Jain, M. and Häggman, H., Eds., Protocols of Propagation for Woody Trees and Fruits, Springer, Dordrecht, 137-146.

[3] Kumar, S., Burdon, R.D., Stovold, G.T. and Gea, L.D. (2008) Implications of Selection History on Genetic Architecture of Growth, Form, and Wood-Quality Traits in Pinus radiata. Canadian Journal of Forest Research, 38, 23722381. http://dx.doi.org/10.1139/X08-086

[4] Greenwood, M.S. (1987) Rejuvenation of Forest Trees. Plant Growth Regulation, 6, 1-12. 
http://dx.doi.org/10.1007/BF00043947

[5] Poethig, R.S. (1990) Phase Change and the Regulation of Shoot Morphogenesis in Plants. Science, 250, 923-930. http://dx.doi.org/10.1126/science.250.4983.923

[6] Díaz-Sala, C., Hutchinson, K. and Greenwood, M. (1996) Maturation-Related Loss in Rooting Competence by Loblolly Pine Stem Cuttings: The Role of Auxin Transport, Metabolism and Tissue Sensitivity. Physiologia Plantarum, 97, 481-490. http://dx.doi.org/10.1111/j.1399-3054.1996.tb00507.x

[7] Diego, L., Berdasco, M., Fraga, M., Cañal, M.J., Rodríguez, R. and Castresana, C. (2004) A Pinus radiata AAA- ATPase, the Expression of Which Increases with Tree Ageing. Journal of Experimental Botany, 55, 1597-1599. http://dx.doi.org/10.1093/jxb/erh171

[8] Heuret, P., Meredieu, C., Courdier, T., Courdier, F. and Barthélémi, D. (2006) Ontogenic Trends in the Morphological Features of Main Stem Annual Shoots of Pinus pinaster. American Journal of Botany, 93, 1577-1787. http://dx.doi.org/10.3732/ajb.93.11.1577

[9] Greenwood, M.S. and Weir, R. (1995) Genetic Variation in Rooting Ability of Loblolly Pine Cuttings: Effects of Auxin and Family on Rooting by Hypocotyls Cuttings. Tree Physiology, 15, 41-45. http://dx.doi.org/10.1093/treephys/15.1.41

[10] Browne, R., Davidson, C., Steeves, T. and Dunstan, D. (1997) Effects of Ortet Age on Adventitious Rooting of Jack Pine (Pinus banksiana) Long-Shoot Cuttings. Canadian Journal of Forest Research, 27, 91-96. http://dx.doi.org/10.1139/x96-160

[11] Greenwood, M.S., Cui, X. and Xu, F. (2001) Response to Auxin Changes during Maturation-Related Loss of Adventitious Rooting Competence in Loblolly Pine (Pinus taeda) Stem Cuttings. Physiologia Plantarum, 111, 373-380. http://dx.doi.org/10.1034/j.1399-3054.2001.1110315.x

[12] Day, M.E., Greenwood, M.G. and White, A.S. (2001) Age-Related Changes in Foliar Morphology and Physiology in Red Spruce and Their Influence on Declining Photosynthesis and Productivity with Tree Age. Tree Physiology, 21, 1195-1204. http://dx.doi.org/10.1093/treephys/21.16.1195

[13] Swarup, R., Parry, G., Graham, N., Allen, T. and Bennet, M. (2002) Auxin Cross-Talk: Integration of Signaling Pathways to Control Plant Development. Plant Molecular Biology, 49, 411-426. http://dx.doi.org/10.1023/A:1015250929138

[14] Valdés, A.E., Fernández, B. and Centeno, M.L. (2004) Hormonal Changes through Maturation and Ageing of Pinus pinea. Plant Physiology and Biochemistry, 42, 335-340. http://dx.doi.org/10.1016/j.plaphy.2004.02.004

[15] Pop, T., Pamfil, D. and Bellinin, C. (2011) Auxin Control in the Formation of Adventitious Roots. Notulae Botanicae Horti Agrobotanici Cluj-Napoca, 39, 307-316.

[16] Lindroth, A.M., Saarikoski, P., Flygh, G., Clapham, D., Roland, G., Thelander, M., Ronne, H. and von Arnold, S. (2001) Two S-Adenosylmethionine Synthetase-Encoding Genes Differentially Expressed during Adventitious Root Development in Pinus contorta. Plant Molecular Biology, 46, 335-346. http://dx.doi.org/10.1023/A:1010637012528

[17] Brinker, M., Van Zyl, L., Liu, W., Craig, D., Sederoff, R., Clapham, D. and von Arnold, S. (2004) Microarray Analyses of Gene Expression during Adventitious Root Development in Pinus contorta. Plant Physiology, 135, 1526-1539. http://dx.doi.org/10.1104/pp.103.032235

[18] Sánchez, C., Vielba, J., Ferro, E., Covelo, G., Solé, A., Abarca, D., De Mier, B. and Díaz-Sala, C. (2007) Two SCARECROW-LIKE Genes Are Induced in Response to Exogenous Auxin in Rooting-Competent Cuttings of Distantly Related Forest Species. Tree Physiology, 27, 1459-1470. http://dx.doi.org/10.1093/treephys/27.10.1459

[19] Solé, A., Sánchez, C., Vielba, J., Valladares, S., Abarca, D. and Díaz-Sala, C. (2008) Characterization and Expression of a Pinus radiata Putative Ortholog to the Arabidopsis SHORT-ROOT Gene. Tree Physiology, 28, 1629-1639. http://dx.doi.org/10.1093/treephys/28.11.1629

[20] Valledor, L., Jorrín, J., Rodríguez, J., Lenz, C., Meijón, M., Rodríguez, R. and Cañal, M.J. (2010) Combined Proteomic and Transcriptomic Analysis Identifies Differentially Expressed Pathways Associated to Pinus radiata Needle Maturation. Journal of Proteome Research, 9, 3954-3979. http://dx.doi.org/10.1021/pr1001669

[21] Kraus, J.E. and Arduim, M. (1997) Basic Manual of Methods in Plant Morphology. EDUR, Rio de Janeiro.

[22] Chang, S., Puryear, J. and Cairney, J. (1993) A Simple and Efficient Method for Isolating RNA from Pine Trees. Plant Molecular Biology Reporter, 11, 113-116. http://dx.doi.org/10.1007/BF02670468

[23] Valledor, L., Cañal, M.J., Pascual, J., Rodríguez, R. and Meijón, M. (2012) Early Induced Protein 1 (PrELIP1) Gene and Other Photosynthetic, Stress and Epigenetic Regulation Genes Are Involved in Pinus radiata D. Don UV-B Radiation Response. Physiologia Plantarum, 146, 308-320. http://dx.doi.org/10.1111/j.1399-3054.2012.01629.x

[24] Pfaffl, M.W. (2001) A New Mathematical Model for Relative Quantification in Real-Time RT-PCR. Nucleic Acids Research, 29, e45. http://dx.doi.org/10.1093/nar/29.9.e45 
[25] Pullman, G. and Timmis, R. (1992) Establishment of Juvenile-Like Shoot Cultures and Plantlets from 4 - 16 Year-Old Douglas-Fir (Pseudotsuga menziesii (Mirb.) Franco) Trees. Plant Cell, Tissue and Organ Culture, 29, 187-198. http://dx.doi.org/10.1007/BF00034352

[26] Hamann, A. (1998) Adventitious Root Formation in Cuttings of Loblolly Pine (Pinus taeda L.): Developmental Sequence and Effects of Maturation. Trees, 12, 175-180. http://dx.doi.org/10.1007/pl00009707

[27] Apple, M., Tiekotter, K., Snow, M., Young, J., Soeldner, A., Phillips, D., Tingey, D. and Bond, B. (2002) Needle Anatomy Changes with Increasing Tree Age in Douglas-Fir. Tree Physiology, 22, 129-136. http://dx.doi.org/10.1093/treephys/22.2-3.129

[28] Boddi, S., Bonzi, L. and Calamassi, R. (2002) Structure and Ultrastructure of Pinus halepensis Primary Needles. Flora-Morphology, Distribution, Functional Ecology of Plants, 197, 10-23. http://dx.doi.org/10.1078/0367-2530-00008

[29] Bond, B. (2000) Age-Related Changes in Photosynthesis of Woody Plants. Trends in Plant Science, 5, 349-353. http://dx.doi.org/10.1016/S1360-1385(00)01691-5

[30] Wolkerstorfer, S., Wonisch, A., Stankova, T., Tsvetkova, N. and Tausz, M. (2011) Seasonal Variations of Gas Exchange, Photosynthetic Pigments, and Antioxidants in Turkey Oax (Quercus cerris L.) and Hungarian Oak (Quecus frainetto Ten.) of Different Age. Trees, 25, 1043-1052. http://dx.doi.org/10.1007/s00468-011-0579-1

[31] Drake, J.E., Davis, S.C., Raetz, L.M. and DeLucia, E.H. (2011) Mechanisms of Age Related Changes in Forest Production: The Influence of Physiological and Successional Changes. Global Change Biology, 17, 1522-1535. http://dx.doi.org/10.1111/j.1365-2486.2010.02342.x

[32] Hutchinson, K., Sherman, C., Weber, J., Smith, S., Singer, P. and Greenwood, M.S. (1990) Maturation in Larch II. Effects of Age on Photosynthesis and Gene Expression Developing Foliage. Plant Physiology, 94, 1308-1315. http://dx.doi.org/10.1104/pp.94.3.1308

[33] Zentgraf, U., Jobst, J., Kolb, D. and Rentsch, D. (2003) Senescence-Related Gene Expression Profiles of Rosette Leaves of Arabidopsis thaliana: Leaf Age versus Plant Age. Plant Biology, 6, 178-183. http://dx.doi.org/10.1055/s-2004-815735

[34] Spreitzer, R. (2003) The Role of Small Subunit in Ribulose-1,5-bisphosphate Carboxylase/Oxygenase. Archives of Biochemistry and Biophysics, 414, 141-149. http://dx.doi.org/10.1016/S0003-9861(03)00171-1

[35] Gao, Y., Yang, F.Q., Cao, X., Li, C.M., Wang, Y., Zhao, Y.B., Zeng, G.J., Cheng, D.M., Han, Z.H. and Zhang, X.Z. (2013) Differences in Gene Expression and Regulation during Ontogenetic Phase Change in Apple Seedlings. Plant Molecular Biology Reporter, 32, 357-371. http://dx.doi.org/10.1007/s11105-013-0648-2

[36] Zhang, Z., Honda, C., Kita, M., Hu, C., Nakayama, M. and Moriguchi, T. (2003) Structure and Expression of Spermidine Synthase Genes in Apple: Two cDNAs Are Spatially and Developmentally Regulated through Alternative Splicing. Molecular Genetics and Genomics, 268, 799-807.

[37] Bagga, S., Rochford, J., Klaene, Z., Kuehn, G.D. and Phillips, C.G. (1997) Putrescine Aminopropyltrnasferase Is Responsible for Biosynthesis of Spermidine, Spermine, and Multiple Uncommon Polyamines in Osmotic Stress Tolerant Alfalfa. Plant Physiology, 114, 445-454.

[38] Paschalidis, K.A. and Roubelakis-Angelakis, K.A. (2005) Spatial and Temporal Distribution of Polyamine Levels and Polyamine Anabolism in Different Organs/Tissues of the Tobacco Plant. Correlations with Age, Cell Division/Expansion, and Differentiation. Plant Physiology, 138, 142-152. http://dx.doi.org/10.1104/pp.104.055483

[39] Fraga, M., Cañal, M.J. and Rodríguez, R. (2002) Phase-Change Related Epigenetic and Physiological Changes in Pinus radiata D. Don. Planta, 215, 672-678. http://dx.doi.org/10.1007/s00425-002-0795-4

[40] Ioannidis, N., Zschiesche, W., Barth, O., Kotakis, C., Navakoudis, E., Humbeck, K. and Kotzabasis, K. (2013) The Genetic Reprogramming of Polyamine Homeostasis during the Functional Assembly, Maturation and Senescence Specific Decline of the Photosynthetic Apparatus in Hordeum vulgare. Journal of Plant Growth Regulation, 33, 77-90. http://dx.doi.org/10.1007/s00344-013-9387-8

[41] Pollman, S., Düchting, P. and Weiler, E. (2009) Tryptophan-Dependent Indole-3-acetic Acid Biosynthesis by IAA Synthase Proceeds via Indole-3-acetamide. Phytochemistry, 70, 523-531. http://dx.doi.org/10.1016/j.phytochem.2009.01.021

[42] Valdés, A.E., Centeno, M.L., Espinel, S. and Fernández, B. (2002) Could Plant Hormones Be the Basis of Maturation Indices in Pinus radiata? Plant Physiology and Biochemistry, 40, 211-216. http://dx.doi.org/10.1016/S0981-9428(02)01371-2

[43] Jiroutová, K., Horák, A., Bowler, C. and Oborník, M. (2007) Tryptophan Biosynthesis in Stramenopiles: Eukaryotic Winners in the Diatom Complex Chloroplast. Journal of Molecular Evolution, 65, 496-511. http://dx.doi.org/10.1007/s00239-007-9022-z

[44] Ramsay, N. and Beverly, G. (2005) MYB-bHLH-WD40 Protein Complex and the Evolution of Cellular Diversity. Transcriptional Networks in Plants, 10, 63-70. http://dx.doi.org/10.1016/j.tplants.2004.12.011 
[45] Zhao, Q., Leung, S., Corbett, A.H. and Meier, I. (2006) Identification and Characterization of the Arabidopsis Orthologs of Nuclear Transport Factor 2, the Nuclear Import Factor of Ran. Plant Physiology, 140, 869-878. http://dx.doi.org/10.1104/pp.105.075499

[46] Cléry, A., Blatter, M. and Allain, F. (2008) RNA Recognition Motifs: Boring? Not Quite. Current Opinion in Structural Biology, 18, 290-298. http://dx.doi.org/10.1016/j.sbi.2008.04.002

[47] Olme-Takagi, M. and Shinshi, H. (1995) Ethylene-Inducible DNA Binding Proteins that Interact with Ethylene-Responsive Element. The Plant Cell, 7, 173-182. http://dx.doi.org/10.1105/tpc.7.2.173

[48] Chao, Q., Rothenberg, M., Solano, R., Roman, G., Terzaghi, W. and Ecker, J.R. (1997) Activation of the Ethylene Gas Response Pathway in Arabidopsis by the Nuclear Protein ETHYLENE-INSENSITIVE3 and Related Proteins. Cell, 89, 1133-1144. http://dx.doi.org/10.1016/S0092-8674(00)80300-1

[49] Solano, R., Stepanova, A., Chao, Q. and Ecker, J.R. (1998) Nuclear Events in Ethylene Signaling: A Transcriptional Cascade Mediated by ETHYLENE-INSENSITIVE3 and ETHYLENE RESPONSE FACTOR1. Genes \& Development, 12, 3703-3714. http://dx.doi.org/10.1101/gad.12.23.3703

[50] Chang, C. and Stadler, R. (2001) Ethylene Hormone Receptor Action in Arabidopsis. BioEssays, 23, 619-627. http://dx.doi.org/10.1002/bies.1087

[51] Felten, J., Vahala, J., Love, J., Gorzsás, A., Gerber, L., Kumar, M., Kangasjärvi, J. and Sundberg, B. (2011) Ethylene Signaling via Ethylene Response Factors (ERFs) Modifies Wood Development in Hybrid Aspen. BMC Proceedings, 5, I15. http://dx.doi.org/10.1186/1753-6561-5-S7-I15

[52] Bleecker, A.B. and Kender, H. (2000) Ethylene: A Gaseous Signal Molecule in Plants. Annual Review of Cell and Developmental Biology, 16, 1-18. http://dx.doi.org/10.1146/annurev.cellbio.16.1.1

[53] Van Loon, L.C., Geraats, B.P. and Linthorst, H.J. (2006) Ethylene as a Modulator of Disease Resistance in Plants. Trends in Plant Science, 11, 184-191. http://dx.doi.org/10.1016/j.tplants.2006.02.005

[54] Lasserre, E., Jobet, E., Llauro, C. and Delseny, M. (2008) AtERF38 (At2g35700), an AP2/ERF Family Transcription Factor Gene from Arabidopsis thaliana, Is Expressed in Specific Cell Types of Roots, Stems and Seeds that Undergo Suberization. Plant Physiology and Biochemistry, 46, 1051-1061. http://dx.doi.org/10.1016/j.plaphy.2008.07.003

[55] Love, J., Björklund, S., Vahala, J., Hertzberg, J., Kangasjärvi, J. and Sundberg, B. (2009) Ethylene Is an Endogenous Stimulator of Cell Division in the Cambial Meristem of Populus. Proceedings of the National Academy of Sciences of the United States of America, 106, 5984-5989. http://dx.doi.org/10.1073/pnas.0811660106

[56] Li, L., Osakabe, Y., Chandrashekhar, P.J. and Chiang, V.L. (1999) Secondary Xylem-Specific Expression of Caffeoyl-Coenzyme A 3-O-methyltransferase Plays an Important Role in the Methylation Pathway Associated with Lignin Biosynthesis in Loblolly Pine. Plant Molecular Biology, 40, 555-565. http://dx.doi.org/10.1023/A:1006244325250

[57] Moyle, R., Moody, J., Phillips, L., Walter, C. and Wagner, A. (2002) Isolation and Characterization of Pinus radiata Lignin Biosynthesis-Related O-Methyltransferase Promoter. Plant Cell Reports, 20, 1052-1060. http://dx.doi.org/10.1007/s00299-002-0457-9

[58] Vincent, D., Lapierre, C., Pollet, B., Cornic, G., Negroni, L. and Zivy, M. (2005) Water Deficits Affects Caffeate OMethyltransferase, Lignification and Related Enzymes in Maize Leaves. A Proteomic Investigation. Plant Physiology, 137, 949-960. http://dx.doi.org/10.1104/pp.104.050815 